\title{
Riparian and aquatic vegetation in Mediterranean-type streams (western Iberia)
}

\author{
M. Teresa Ferreira \& Francisca C. Aguiar \\ Forest Research Centre, Instituto Superior de Agronomia, Tapada da Ajuda 1349-017 Lisbon, Portugal. \\ Corresponding author: M. T. Ferreira, terferreira@isa.utl.pt
}

\begin{abstract}
Floral composition and structural patterns displayed by the aquatic and riparian vegetation in Mediterranean-type streams show distinctive features when compared to mesic fluvial systems. In this paper we sum up two decades of studies on the ecology of riparian and aquatic vegetation in western Iberia (Portugal). We present results concerning the structural patterns of the riparian woody vegetation, its variation in space and time, and its role in fluvial processes. We give an overall description and ecological appraisal of the riparian and aquatic flora and its complex relationships with abiotic drivers from both the river corridor and the drainage basin. We also describe our observations of floral disturbances derived both from natural and human causes. We have taken various approaches to assessing ecological quality using river plants, and these are also reviewed. The overall results obtained in these last twenty years are discussed as a contribution to future research needs.
\end{abstract}

Keywords: river plants, fluvial corridors, flora, ecology, disturbance, integrity, Portugal.

\section{RESUMEN}

La composición florística y los patrones estructurales de la vegetación acuática y riparia en ríos mediterráneos muestran caracteristicas diferenciales cuando son comparados con sistemas fluviales templados. En este trabajo, intentamos reunir dos décadas de estudios sobre la ecología de la vegetación riparia y acuática en Iberia Occidental (Portugal). Presentamos resultados acerca de los patrones estructurales de la vegetación leñosa riparia, su variación espacio-temporal, y su papel en los procesos fluviales. Hacemos una descripción global y un abordaje ecológico de la flora riparia y acuática y sus complejas relaciones con los factores abióticos, desde la escala del corredor fluvial hasta la cuenca de drenaje. Describimos también las perturbaciones observadas sobre la flora, tanto derivadas de causas naturales como humanas. Hemos desarrollado algunos enfoques para evaluar la calidad ecológica utilizando plantas y estos son también revisados. Se discuten los resultados obtenidos en estos últimos veinte años con el objetivo de contribuir para la determinación de futuras necesidades en la investigación.

Palabras clave: plantas de río, corredores riparios, flora, ecología, perturbación, integridad, Portugal.

\section{INTRODUCTION}

Though the term riparian commonly appears in many titles concerning the ecology of river systems, ecological studies dealing with riparian and aquatic vegetation per se are a minority and much less common than those addressing other biological communities. River plants thrive somewhere between vegetation science and landscape ecology and are not as frequently found in limnological journals. Nonetheless, noticeably active areas of research include studies related to distribution patterns (Haslam,
1987; Nilsson et al., 1989; Wiegleb et al., 1989; Szaro, 1990; Holmes et al., 1998; Riis et al., 2000), functional traits and groups (Ali et al., 1999; Willby et al., 2000; Lyon \& Sagers, 2002), dynamic processes mediated by instream vegetation (Décamps et al., 1988, Henry et al., 1996; Cooper et al., 2003), and invasive pathways and man-made disturbances (Nilsson et al., 1991; Planty-Tabbachi et al., 1996; Stohlgren et al., 1999; Baattrup-Pedersen \& Riis, 1999; Hood \& Naiman, 2000). These pieces of information eventually become cemented in reviews and books (Nilsson \& Svedmark, 2002; Naiman et 
al., 2005). Once in a while, people also ask themselves just what well preserved river vegetation is, and how can we quantitatively translate it into ecological quality (Haury et al., 1996; Salinas et al., 2000; Schneider \& Melzer, 2003; Schaumburg et al., 2004; Dodkins et al., 2005). Studies on the ecology of riparian and aquatic vegetation in Mediterranean-type and semi-arid streams are even fewer in number (Kondolf et al., 1987; Szaro, 1990; Stromberg, 1993; Hancock \& Froend, 1996).

At the beginning of the nineteen-eighties Iberian limnological botany was just learning to walk. As usual, Ramon Margalef was an attentive father, and his influence was felt through his teachings in limnology, either at the University of Barcelona, or at the Instituto de Altos Estudos Mediterráneos de Zaragoza, where, in her early limnological beginnings, one of the authors (M.T.F.) was fortunate enough to learn from him. Over the subsequent years Spanish limnological botany continued to move forward, either exploring distribution patterns of river plant communities and their environmental drivers (Peñuelas \& Sabater, 1987; Onaindia et al., 1996; Fernández-Aláez et al., 2005), or trying to understand changes influenced by humans (Romero \& Onaindia, 1995; Salinas et al., 2000; Corbacho et al., 2003). In Portugal most studies on the ecology of riparian and aquatic plants were centred on weed vegetation (Ferreira \& Moreira, 1990; Aguiar et al., 1996; Ferreira et al., 1998a; Moreira et al., 1999a; Bernez et al., 2002; Aguiar et al., 2005a) and conservation assessments (Ferreira, 1994a; Espírito-Santo et al., 2000; González et al., 2003; Aguiar et al., 2004; Moreira et al., 2004). However, from the late eighties onwards a persistent line of work also grew up in relation to distribution patterns, the magnitude and drivers of alien invasions, and ecological quality - an accumulation of small building blocks of knowledge. In this paper we attempt to summarize these twenty years of studies on the ecology of riparian and aquatic vegetation in western Iberia (Portugal), and to establish how much we know, so that future lines of progress can be sketched out.

\section{RIPARIAN WOODS IN WESTERN IBERIA: STRUCTURE, DYNAMICS AND FUNCTION}

By supporting a wide range of biotic assemblages in a seasonally water-stressed environment, riparian woody vegetation in Iberia constitutes a central element in the Mediterranean landscape (Gasith \& Resh, 1999). In Iberia riparian corridors emerge from the surrounding landscapes as "linear oases" (González-Bernáldez et al., 1989) with particular structural and compositional features. This is particularly evident in central and southern Portuguese basins, where the climatic harshness and the flashflow hydrological regime are especially marked, and the term "riparian gallery" can be used with its proper meaning. By combining the interpretation of aerial photographs with field surveys, Aguiar \& Ferreira (2005) analysed the riparian canopy width and longitudinal riparian continuity and the different uses of the adjacent lands along approximately $600 \mathrm{~km}$ of eight tributaries of the River Tagus (Central Portugal). The riparian galleries were consistently narrow, up to a maximum of 24 metres, with an average riparian canopy width per river ranging from around 3 to 10 metres. It was observed that the riparian canopy width differed both along the longitudinal river gradient and between river corridors (Fig. 1). Some watercourses had wider riparian formations at mid-course than in the lowland and headwater areas, whilst others revealed upstream-downstream increases in width. In rivers that were highly fragmented by dams (Fig. 1; Zêzere River) no clear spatial patterns emerged. Naturally narrow galleries composed of tree heath (Erica arborea L.), black elder, (Sambucus nigra L.) and dyer's buckthorn (Frangula alnus Mill.) were located at the rocky headwaters of the northern basins, while upstream southern reaches also presented narrow riparian strips composed of resilient species such as the African tamarisk (Tamarix africana Poir.) and the rose-bay (Nerium oleander L.), which are adapted to dryness. Wider riparian formations, such as those of the sou- 


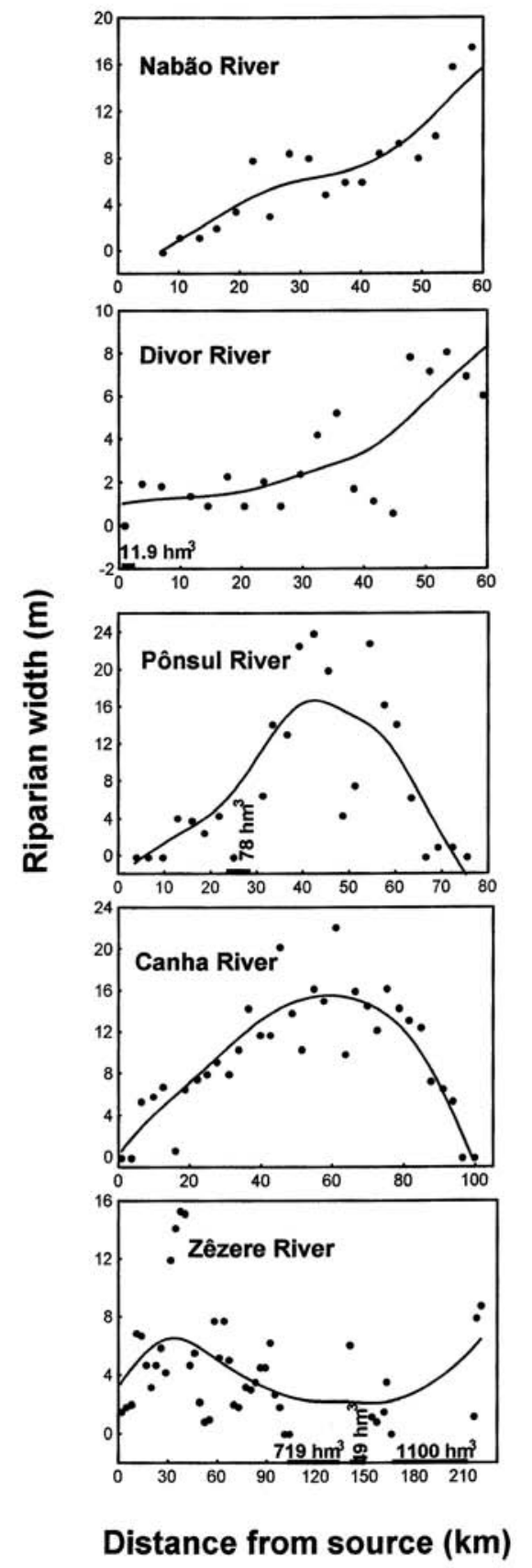

Figure 1. Spatial variation of riparian canopy width along five tributaries of the Tagus River. Note the different scales. Curves were fitted according to the distance-weighted least squares. Location, extension and gross capacity of reservoirs are given (adapted from Aguiar \& Ferreira, 2005). Variación espacial de la anchura del bosque ripario a lo largo de cinco afluentes del rio Tajo. Notar las diferentes escalas. Las curvas fueron ajustadas según el método de mínimos cuadrados. En cada río se indica la localización, área y capacidad de los embalses (Adaptado de Aguiar \& Ferreira, 2005). thern shallow river valleys (see Fig. 1; midstreams of the River Canha and upstream reaches of the River Divor), were characterized by continuous stands of willows (Salix alba group and S. salviifolia) associated with irrigation crops in the surrounding area or following silting and nutrient enrichment of the river system (Ferreira, 1994b; Ferreira, 1994c).

Whilst the riparian formations varied in composition and width depending on the natural features of river geomorphology and water scarcity, land-use, and the upstream-downstream river gradient, the patchy pattern of longitudinal continuity and the widespread fragmentation of riparian woods is mainly a response to human disturbances within the fluvial corridors (Salinas et al., 2000; Aguiar \& Ferreira, 2005). Gallego-Fernández et al. (1999) suggested that the riparian galleries in this region are remnants of wider pre-historic riparian formations, which have been structured and degraded by a millenary human influence and by a decrease in water availability from surface and sub-superficial runoff. In addition to agriculture, grazing and deforestation, a large number of "recent" human activities along a river and across its floodplain are known to influence riparian vegetation (see reviews of Malanson, 1993; Kondolf et al., 1996). These include urbanization, surface mining, water abstraction, pollution, flow regulation and also regional and worldwide global changes (Naiman et al., 2005).

In a snapshot survey of a 35 to 45 -year study period, Ferreira et al. (2005) identify significant spatio-temporal land-use changes on the floodplains adjacent to Iberian river basins, either accompanied by remarkable differences in riparian structure, or without significant alterations in the longitudinal patterns of stand canopy closure. Furthermore, neither fragmentation patterns nor the loss of or increase in riparian cover were consistent with similar land-use changes, particularly in urbanizing landscapes. Figure 2 shows the spatial variation of riparian canopy width and length of continuous canopies of two rivers with diverse land-use features. Differences in land use between river basins can be seen in figure 3 . 
Nabão River
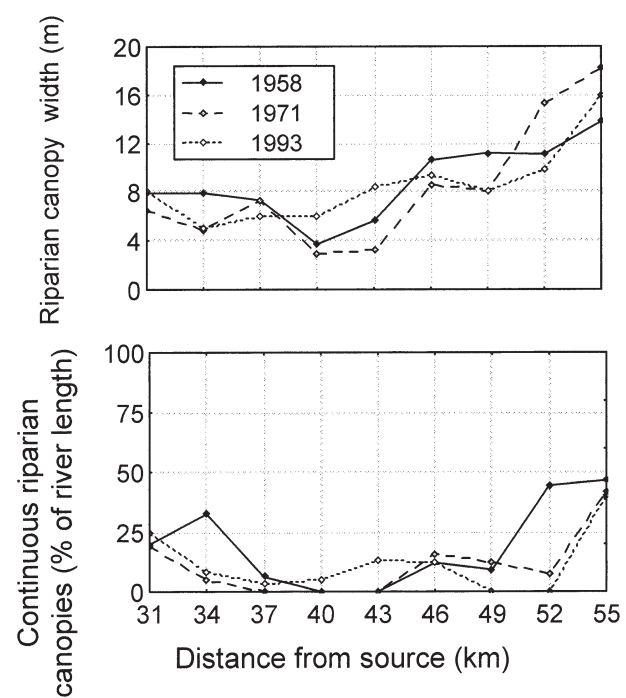

Canha River
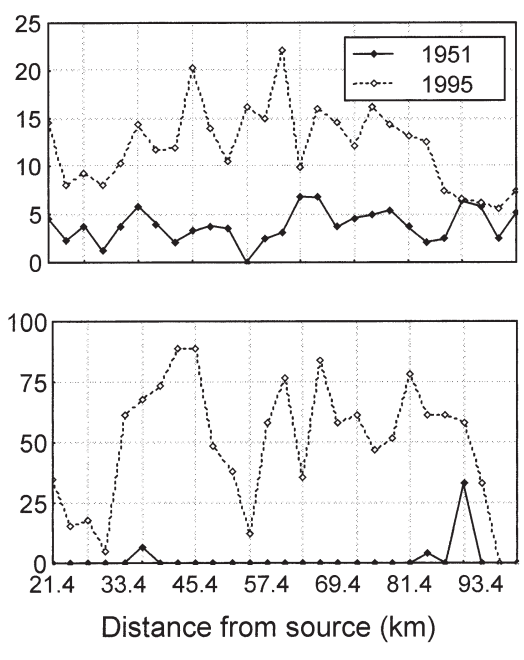

Figure 2. Spatial variation of riparian width and of riparian wood continuity (\% of river length) for the Canha and Nabão rivers, on different flyover dates (adapted from Ferreira et al., 2005). Variación espacial de la anchura y continuidad del bosque ripario (\% de longitud del rio) para los ríos Canha y Nabão, en diferentes fechas de vuelo. (Adaptado de Ferreira et al., 2005).

Although many small-scale changes in land use have occurred with time and have influenced riparian patchiness locally, a considerable amount of change is needed in order to detect significant alterations in canopy structure (cover, width or patchiness). There is evidence that both the proximity and extension of landuse patches interplay so as to influence the degree of changes in riparian structure (lateral and longitudinal features), which in overall terms displayed a great resistance to indirect disturbance (Ferreira et al. 2005). When it comes to the direct alterations within the riparian corridor, and particularly in lowland river systems, the resilience of riparian woody communities can be very high. Following radical clear-cuts and dredging of the fluvial corridor, Ferreira \& Moreira (1990) observed recovery periods as short as four years for both canopy development and basal area. Also, Aguiar et al. (2001) studied riparian species assemblages (richness and cover) along a lowland river segment 12 years after river channelization, and compared it to less impacted reaches nearby. The channelization project included reprofiling by dredging, straightening and two-stage bank reinforcement. Following the relative substrate and slope stabi- lisation of the newly created embankment, the woody species assemblages of the first terrace recovered, displayed the general structure and composition of those encountered in nearby 'natural' reaches, and confirmed their potential performance as pioneers in Iberian rivers (as Gasith \& Resh (1999) pointed out in relation to Mediterranean rivers). However, this was not true for in-stream species assemblages, overstorey communities and the $2^{\text {nd }}$ terrace, which correspond to the peripheral boundary with adjacent lands, and there was a shift in species composition, with a significant increase in the abundance and number of alien species (Fig. 4).

Woody formations are highly dynamic functional entities that exchange matter (including biota) and energy with the adjacent land, as well as on its vertical and longitudinal dimensions (Ward et al. 2002). Though appearing to be disproportionately narrow compared to surrounding ecosystems, riparian galleries in western Iberia are very important to the sustainability of biotic communities (e.g. mammals, birds, fish, benthic macroinvertebrates), given that they promote physical habitat heterogeneity and instream patchiness, create favourable microclimates, and participate in the trophic webs and in global and 


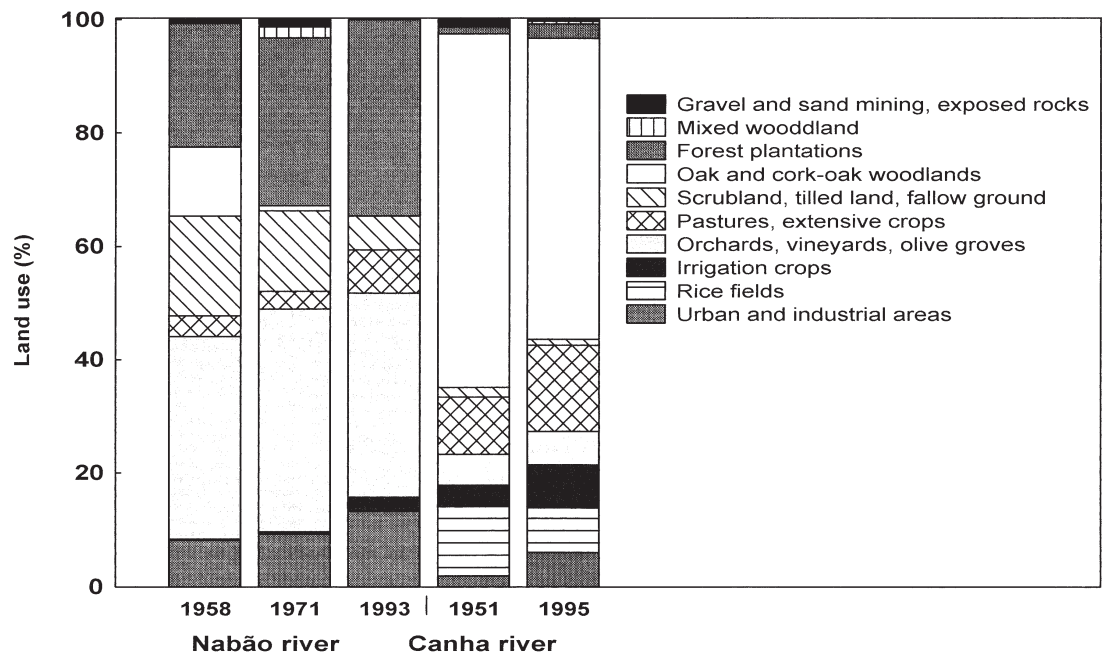

Figure 3. Changes in land use classes in the Nabão and Canha basins (given as \% of $1000 \mathrm{~m}$-valley) (adapted from Ferreira et al., 2005). Cambios en las clases de uso del suelo en las cuencas del Nabão y Canha (valores porcentuales estimados para $1000 \mathrm{~m}$ de anchura del valle). (Adaptado de Ferreira et al., 2005).

regional biogeochemical cycles. The successional dynamics of the riparian vegetation and its varying (rarely monospecific) composition contribute to its success or weakness as a conduit for nutrients, organisms and energy. For instance, in the temporary south-western streams of Portugal,

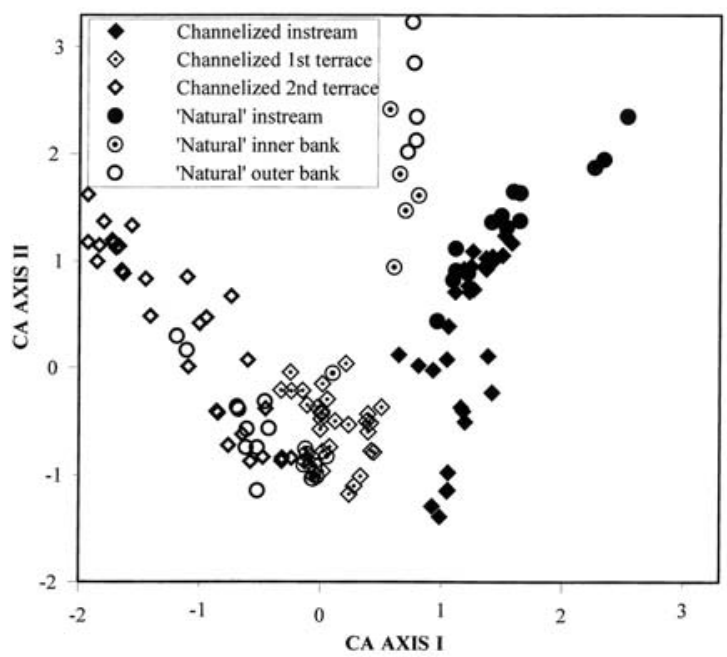

Figure 4. Axes one and two of the correspondence analysis (CA) using the floristic composition of 54 transects from the nine channelized and 'natural' sites studied in the Mondego river lowlands (adapted from Aguiar et al., 2001). Primer y segundo eje del análisis de correspondencias (CA) utilizando la composición florística de 54 transectos de las 9 localidades canalizadas y "naturales", estudiadas en el tramo final del rio Mondego (Adaptado de Aguiar et al., 2001).
Aguiar et al. (2002) found that macroinvertebrate communities were more dependent on riparian features - namely cover, overhanging tree shade, and abundance of ash (Fraxinus angustifolia Vahl.) and alder (Alnus glutinosa Mill.) - than on environmental factors. However, many southern Iberian woody species are poor in food quality and availability for macroinvertebrate consumption. Some have scale-like leaves (e.g. tree heath, African tamarisk), while others (e.g. the hawthorn, Crataegus monogyna Jacq.) have hard, sclerophyllous leaves or a strong pubescence (e.g., S. salviifolia Brot.).

\section{AQUATIC AND RIPARIAN FLORA: RICHNESS, COMPOSITION, REGIONAL FEATURES AND LATERAL CONNECTIVITY}

In most Iberian rivers the flora possesses a naturally low richness in truly aquatic species - i.e. hydrophytes (Ferreira, 1994c; Ferreira et al., 1998b; Ferreira \& Moreira, 1999) - compared to that found in mesic fluvial systems (Haslam, 1987; Naiman et al., 1993). What is more, these species are frequently ubiquitous and highly tolerant to adverse abiotic conditions, and tend to develop large mono-specific stands whenever 
their specific requirements are fulfilled - something that is normally caused by human-induced disturbances, such as water pollution and the enrichment in nutrients due to agricultural inputs. In a field survey of 77 sampling locations $(100 \mathrm{~m}$-long river segment) of the Sado river basin (south-western Portugal) Ferreira et al. (2004) observed that only $3 \%$ of the flora recorded were hydrophytes and $5 \%$ helophytes (i.e. emergent species). They attributed this low richness to the hydrological intermittency of the rivers, and to human interferences in the flow regime - particularly water abstraction. In a nationwide study Aguiar et al. (2006) observed similar features for minimally disturbed sites (i.e. reference sites). Figure 5 displays the numbers of hydrophytes, helophytes, hygrophytes, and terrestrial species for the fluvial corridor (riverbed and margins) and for the river channel at 205 reference sites on Portuguese watercourses (includes bryophytes and vascular plants). The endemic elements make a generally low contribution (around $4 \%$ to $5 \%$ ) to the overall flora recorded in fluvial corridors, either under reference conditions (Fig. 5), or at impaired sites (Aguiar et al., in press). The contribution of alien taxa to the total flora of Iberian type streams is low (Tabacchi et al., 1996; Aguiar et al., 2005b) when compared to semi-arid rivers in South Africa, western North America and southwestern France, where the proportion of alien taxa ranges from $20 \%$ to $30 \%$ (Planty-Tabacchi et al., 1996, Hood \& Naiman, 2000). General proportions of alien plant species range from around $4 \%$ to $10 \%$ in central and southern Portuguese basins (Aguiar et al., 2005b), and from around $6 \%$ to $8 \%$ for south-eastern Spain (Tabacchi et al., 1996). Alien taxa are widespread in Portuguese fluvial corridors; even under near-natural conditions, in Portuguese streams the proportion of alien species reaches $8 \%$ of the total flora recorded (Aguiar et al., 2006; Fig. 5). However, disturbed sites display a significantly higher susceptibility to invasion than near-natural locations (Ferreira \& Moreira, 1995; Hood \& Naiman, 2000; Aguiar et al., 2001; Aguiar et al., in press). Thus, patterns of invasibility in Iberian rivers should not only include studies of species richness, but also estimates of abundance, such as foliar cover or biomass (Aguiar et al., 2001). In fact, invasions by alien plant species in Mediterranean fluvial corridors are frequently due to just one or a small number of strong competitors, such as the water-hyacinth (Eichhornia crassipes Mart.-Solms.), the parrot-feather (Myriophyllum aquaticum (Vell.) Verdc.), and the giant-reed (Arundo donax L.). Aguiar et al. (2005b) studied the patterns of species richness and cover for alien and native plant species along a typical Mediterranean river, and across its floodplain. Unlike the richness and native cover trends, the alien cover was significantly higher in inundated areas than in upland ones. The excessive growth of both native and alien species in other water bodies, such as swamps and ponds, reservoirs, and drainage and irrigation channels is also common (Aguiar et al., 1996). Various studies have been carried out in Portugal on aquatic weed assemblages (both native and alien) and the underlying environmental factors (e.g. Ferreira \& Moreira 1990; Ferreira et al. 1998a; Aguiar et al., 2005a), the bioecology of species and its control (e.g. Moreira et al., 1989;

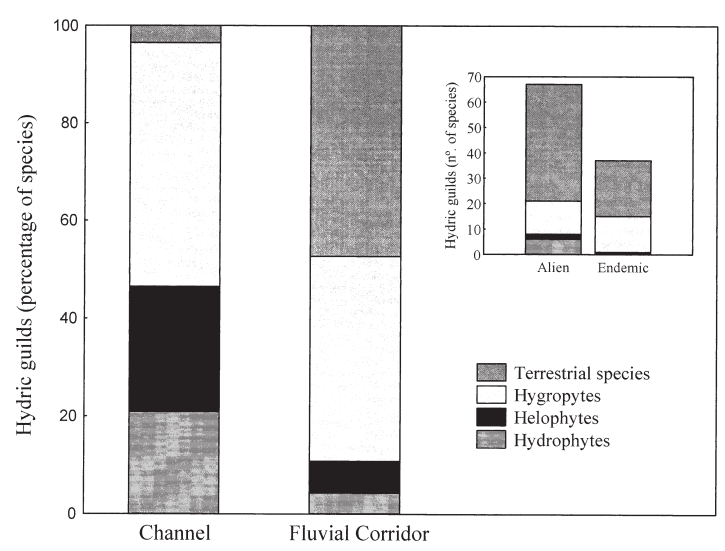

Figure 5. Proportion of total species recorded by hydric guilds in the river channel and in the fluvial corridor, and by species origin for the overall flora recorded at 205 reference sites on Portuguese watercourses (adapted from Aguiar et al., 2006). Proporción del total de especies registradas por grupos hídricos en el interior del río y en el corredor fluvial, y por origen de las especies para la flora global registrada en 205 localidades de referencia en ríos portugueses (Adaptado de Aguiar et al., 2006). 
Catarino et al., 1997; Moreira et al., 1999b), and relations between species traits and invasive species (Bernez et al., 2002).

Another particularity of the life-form spectra in this region is the huge proportion of terrestrial species - that is, non-waterlogged species (Fig. 5). The terrestrial species' introspection in the fluvial corridor was also maintained when we looked at the species' origin (alien and endemic). These terrestrial species are usually infrequent or site-specific, and are highly dependent on the adjacent land-use and the intricate geomorphological background (Aguiar \& Ferreira, 2005). The heterogeneity of the surrounding land contributes to a diverse species pool, which was confirmed by a clear species overlap between uplands and the fluvial corridor (Aguiar et al., 2005b). Most of the terrestrial species are opportunistic and generalist ones, such as adventitious weeds, ruderals, or nitrophyllous or sclerophyllous species that are typical of Mediterranean scrublands. The colonization of riverbanks by terrestrial species is particularly evident in Mediterranean rivers in southern basins, due to climatic harshness and intermittent flows (Ferreira \& Moreira, 1998b; Ferreira et al., 2004).

The low proportions of waterlogged species observed could be an effect of the year or the season in which the floristic sampling took place. Although large intra-annual differences frequently occur in this Mediterranean region, with an alternation between extremely dry periods and wet years, Ferreira et al. (2001) observed that the richness and percentage of rare and less abundant species did not change much in different hydrological years, though spring surveys display significantly smaller differences in the total number of species per site and in the terrestrial species richness than do summer surveys. The late spring / early summer was found to be the best period for floristic sampling, especially when using oneshot surveys. However, due to the marked Mediterranean climate conditions in the southern basins, floristic surveys over a large latitudinal range should preferably be conducted from south to north. Besides the hydrological regime, river plants are known to be directly or indirectly related with a large number of environmental factors that contribute to the processes, the functioning and the structural identity of the riparian ecosystems in western Iberia. To date, studies carried out at the catchment level (e.g. Ferreira \& Smeding 1990; Ferreira, 1994d; Ferreira, et al., 1998b; Ferreira \& Moreira, 1999; Aguiar et al., 2000) have shown a low floristic cohesiveness of plant grouping, and a weak relationship with abiotic variables. Figure 6 presents the canonical correspondence analysis (CCA) biplots of environmental variables and of woody species of: (a) $97 \mathrm{sam}-$ pling locations on the River Tagus (Central Portugal); and (b) a subset of 34 minimally disturbed sites. A gradient between cooler northern permanent rivers running through V-shaped valleys with considerable slope, and the drier and warmer southern tributaries and river lowlands was displayed. For a Tagus tributary Ferreira \& Moreira (1999) observed analogous patterns for aquatic and waterlogged species, with the major environmental gradients being the river hierarchy (and the related variables altitude, order number, site drainage area, geoclimatic regime), along with human-disturbance, and the substrate. Also, Fernández-Alaéz et al. (2005) established a typology for the largest river basins in north-western Iberia, using classification and ordination techniques to determine the underlying environmental gradients. Similarly, the main variables affecting riparian vegetation were altitude, geomorphological features, and disturbance factors that were mainly related with pollution. In Iberian river plants generally respond to large geographical asymmetries, to the river gradient, and to local or habitat features, such as the substrate or physical alterations of the river profile. In fact, human disturbance appears to be a key factor in this entanglement and in the difficulty in obtaining clear regional groups. The identification of reference conditions is thus a critical stage for plant groupings and their geographic affiliation, and also to bioassessment and the ecological monitoring of river health (Aguiar et al., 2000; Ferreira et al., 2002). 

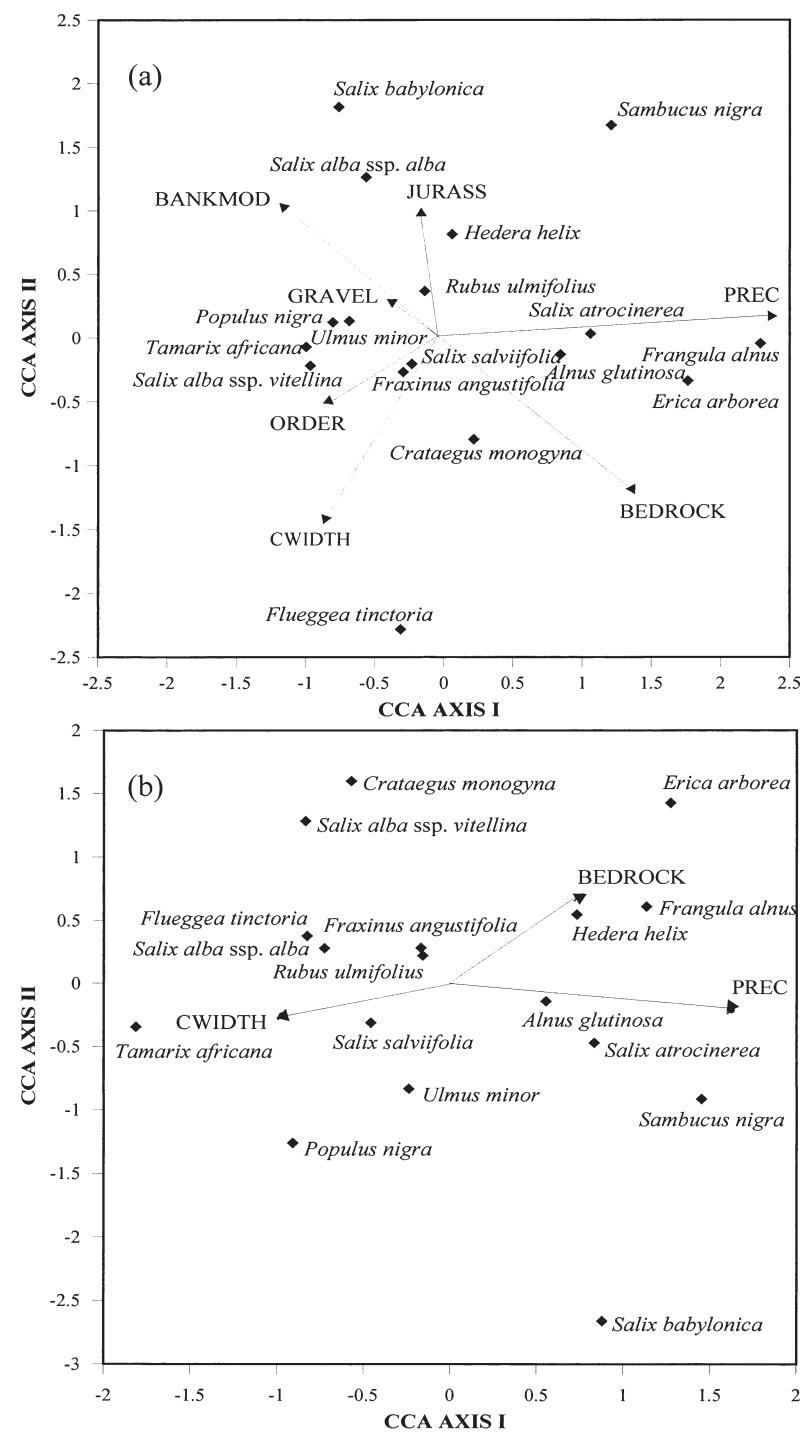

Figure 6. Biplot of the canonical correspondence analysis (CCA) using (a) 97 sampling locations in the Tagus basin, and (b) a subset of reference sites, showing the spatial distribution of the woody species and the environmental variables. BANKMOD-anthropogenic bank modification; BEDROCK-bedrock; GRAVEL- gravel and pebble; JURASS-Jurassic geological elements; ORDERStrahler's order number; PREC-yearly average precipitation; CWIDTH- average channel width (adapted from Aguiar et al., 2000). Gráfico del Análisis de Correspondencias Canónicas (CCA) utilizando (a) 97 localidades de muestreo en la cuenca del Tajo y (b) un subgrupo de localidades de referencia, mostrando la distribución espacial de las especies leñosas y las variables ambientales. BANKMOD-modificación antrópica del talud; BEDROCK-roca madre; GRAVEL-piedras de 2 a $10 \mathrm{~cm}$; JURASS-Elementos geológicos jurasicos; ORDER-Número de orden del tramo de río según Strahler; PREC-Precipitación media anual; CWIDTH- anchura media del lecho del río (Adaptado de Aguiar et al., 2000).

\section{RIVER PLANTS AND RIVER QUALITY ASSESSMENT IN WESTERN IBERIA}

In the last few years several approaches to the assessment of river quality using river plant responses to disturbance have been developed.
Taxon-based indicators have been used in water quality assessments and in plant indices, such as the MTR (Holmes et al., 1999) and the IBMR (Haury et al., 1996). However, it is very difficult to find key species in Mediterraneantype streams and in dryland areas, where the 
herbaceous vegetation in the channel is dominated by tolerant emergent species or by hygrophilous species, and in an environment that is characterized by multi-faceted disturbances. Predictive models at the community level (species composition, species abundance) seek to measure the deviation of a given sampling location (or test site) from the correspondent geographical reference (or reference river type), and the use of the taxa ordination space or weighted probabilities of taxa occurrence is known as a multivariate approach. After defining the river types by classification, Ferreira et al. (2002) successfully used the Bray-Curtis multivariate distance to quantify the ecological deviations of plant communities in a southern Iberian river (Fig. 7). The use of an overall canonical procedure to identify reference conditions was one of the novelties of this work, and it was emphasized that it could be a good alternative for regions where not much environmental data is available and regional river types are unclear - as was the case in the studied area.
Although generally based on other biological elements and far less on plants, the multimetric approach uses the quartile distributions of community attributes or metrics, is well developed, and is widely applied in the USA and other parts of the world (Karr \& Chu, 2000). User-defined and ecologically meaningful community descriptors and groups of certain taxa (plant guilds), and quantitative expressions such as diversity and equitability, often respond significantly to disturbance, and can also be used in plant quality assessment (e.g. de Lange \& van Zon, 1983; Nichols et al., 2000; Thiebaut et al., 2002). Also, species traits such as morphological features can be used as metrics, since they summarize survival strategies (e.g. Bornette et $a l ., 1994)$ and reflect disturbance regimes (Noble \& Slatyer, 1980; Henry et al., 1996). Ferreira et al. (2005) developed a multimetric index - the IMPI (Iberian Multimetric Plant Index ) - for the rivers of the Algarve in southern Portugal. After identifying two vegetation types, a partial canonical correspondence analysis of
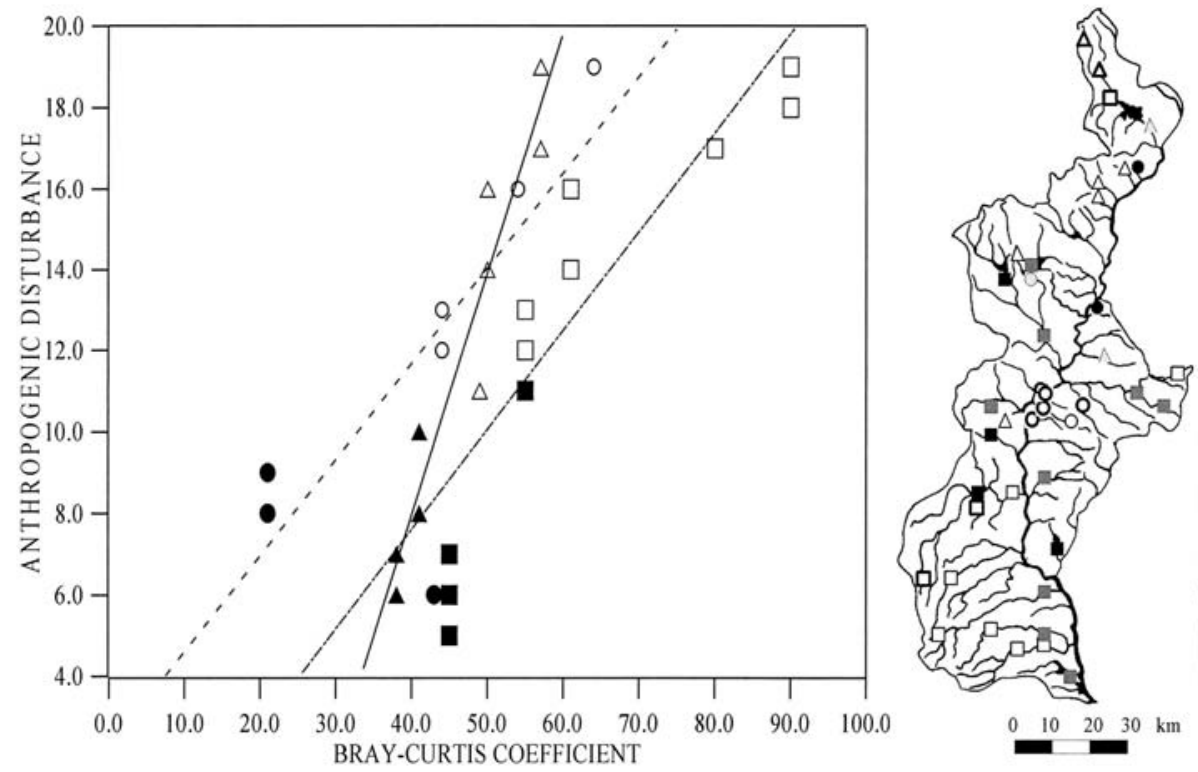

Sampling sites

$\triangle$ Northern siliceous

O Calcareous

$\square$ Southern siliceous

Floristic deviation

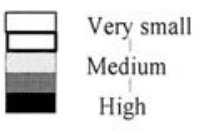

Figure 7. Map of the studied basin with the location of sampling sites per river type (right figure), and linear regression of BrayCurtis dissimilarity against the anthropogenic disturbance (left figure). Symbols filled in in black indicate the reference sites for each river type. A few symbols represent more than one site with the same dissimilarity value (adapted from Ferreira et al., 2002). Mapa de la cuenca estudiada con la localización de las localidades de muestreo por tipo de río (figura de la derecha), y regresión lineal de la disimilaridad de Bray-Curtis frente a la perturbación antrópica (figura de la izquierda). Los símbolos en blanco indican los sitios de referencia para cada tipo de río. Algunos símbolos representan más de una localidad con el mismo valor de disimilaridad (adaptado de Ferreira et al., 2002). 
the floristic data with anthropogenic variables permitted the recognition of the least impaired sites, using the abiotic factors as co-variables to account for natural site variability. Of the 22 candidate-metrics used, eight were selected for inclusion in the final additive multimetric index: three representing composition measures (number of riparian and aquatic species, and number of annual species), three reflecting direct human-disturbances (abundance of the alien species Arundo donax, number of alien species, number of ruderal species), one trophic measure (number of nitrophyllous species), and one related with riparian integrity (relative riparian width). The Iberian Multimetric Plant Index (IMPI) displayed the potential to relate riparian vegetation features to the current range of global disturbance, but it requires further validation for other Iberian river basins.

Recently, Dodkins et al. (2005) used canonical correspondence analysis to determine the deviation of aquatic macrophytes from reference conditions in the rivers of Northern Ireland, using the multivariate optima and niche breadth of the species to obtain response metrics along environmental gradients. Most of these studies directly or indirectly contribute to the implementation of the Water Framework Directive (WFD) (Directive 2000/60/EC, European Council, 2000). The European Union approved the WFD at the end of 2000. It requires all European Member States to develop methods for measuring and monitoring the ecological status of surface waters, so as to achieve a "good ecological status" by 2015. The first steps in the implementation of the WFD are typological classification, the definition of reference sites, and the classification of water bodies. River plants are one of the biological elements that are included as potential indicators of ecological quality, for use in the bioassessment and monitoring of the ecological status of water bodies. For the purposes of the Portuguese transposition of the WFD, the data treatment using macrophytes from reference sites (unpublished data) was consistent with the predetermined abiotic typology, and made it possible to clearly define plant groups.

\section{FINAL REMARKS}

River plants and riparian vegetation are an important element in Mediterranean streams, but are frequently overlooked in limnological studies. We have demonstrated that in western Iberian rivers present diverse and dynamic plant communities, which are intensively interconnected with lateral and vertical ecotones and have multi-scaled biotic drivers that act in both space and time. Natural and human disturbances are entwined forces that shape river vegetation, to the point that undisturbed plant communities are difficult to find or characterize. Though truly aquatic species are few, Mediterranean river plants nonetheless play an important role in stream functions, and functional parts or the entire plant community could therefore be used as a measure of losses of ecological integrity. Future research should focus on a further search for reference (least-disturbed) community types and the validation of quality assessment tools, on particular aspects of community changes, such as ongoing invasive processes, and on the effects of particularly important abiotic drivers - such as hydrological and climate changes.

\section{REFERENCES}

AGUiAR, F., J. C.COSTA, M. LOUSÃ \& I. MOREIRA. 2004. Vegetação aquática e ribeirinha da bacia do Sado. In: Gestão ambiental dos sistemas fluviais. Aplicação à bacia hidrográfica do rio Sado. I.S. Moreira, M.G Saraiva. \& F. Nunes Correia (eds.): 227-246. ISAPress, Lisbon, Portugal.

AGUIAR, F. C. \& M. T. FERREIRA 2005. Human-disturbed landscapes: effects on composition and integrity of riparian woody vegetation in the Tagus River basin, Portugal. Environmental Conservation, 32(1): 30-41.

AGUIAR, F. C., I. MOREIRA \& M. T. FERREIRA. 1996. A percepção da vegetação aquática infestante pelas entidades gestoras dos recursos hídricos. Revista da Ciências Agrárias, 19(4): 35-56.

AGUiAR, F. C., M. T. FERREIRA \& A. ALBUQUERQUE. 2005b. Patterns of exotic and native plant species richness and cover along a semi-arid Iberian river and across its floodplain. Plant 
Ecology (on-line issue; DOI: 10.1007/s11258005-9064-5)

AGUIAR, F. C., M. T. FERREIRA \& I. MOREIRA. 2001. Exotic and native vegetation establishment following channelization of a western Iberian river. Regulated Rivers: Research \& Management, 17: 509-526.

AGUIAR, F. C., M. T. FERREIRA \& P. PINTO. 2002. Relative influence of environmental variables on macroinvertebrate assemblages from an Iberian basin. J. North Am. Benthol. Soc., 21(1): 43-53.

AGUiAR, F. C., M. T. FERREIRA, A. ALBUQUERQUE \& I. MOREIRA. (In press) Alien and endemic flora at reference and non-reference sites on Mediterranean-type streams in Portugal. Aquatic Conservation: Marine \& Freshwater Ecosystems.

AGUIAR, F. C., M. T. FERREIRA, A. ALBUQUERQUE \& I. BERNEZ. 2005a. Invasibility patterns of knotgrass (Paspalum distichum) in Portuguese riparian habitats. Weed Technology, 19(3): 509516.

AGUIAR, F. C., M. T. FERREIRA, P. RODRÍGUEZGONZÁLEZ, A. ALBUQUERQUE, C. SÉRGIO \& J. M. SANTOS. 2006. Flora Macrofítica como Indicadora da Qualidade Ecológica de Sistemas Fluviais Portugueses. Actas do $8^{\circ}$ Congresso da Água, Figueira da Foz, Portugal (edited in CD-ROM).

AGUIAR, F. C., M. T. FERREIRA, I. S. MOREIRA \& A. ALBUQUERQUE. 2000. Riparian types in a Mediterranean basin. Aspects of Applied Biology, 58: 221-232.

ALI, M. M., K. J. MURPHY \& V. J. ABERNETHY. 1999. Macrophyte functional variables versus species assemblages as predictors of trophic status in flowing waters. Hydrobiologia, 451: 131-138.

BAATTRUP-PEDERSEN, A. \& T. RIIS. 1999. Macrophyte diversity and composition in relation to substratum characteristics in regulated and unregulated Danish streams. Freshwat. Biol., 42: 375-385.

BERNEZ, I., C. VIOLLE \& M. T. FERREIRA. 2002. Species traits as a tool for aquatic and riparian plant invasion: survey in Portugal. Proceedings of the $11^{\text {th }}$ EWRS International Symposium on Aquatic Weeds. Moliets et Maa, France: 87-90.

BORNETTE, G., C. HENRY, M. H. BARRAT \& C. AMOROS. 1994. Theoretical habitat templets, species traits, and species richness: aquatic macrophytes in the Upper Rhône River and its floodplain. Freshwat. Biol., 31: 487-505.
CATARINO, L. F., M. T. FERREIRA \& I. S MOREIRA. 1997. Preferences of grass carp for macrophytes in Iberian drainage channels. Journal of Aquatic Plant Management, 36: 79-83.

COOPER, D. J., D. C. ANDERSEN \& R. A. CHIMNER. 2003. Multiple pathways for woody plant establishment on floodplains at local and regional scales. Journal of Ecology, 91: 182-196.

CORBACHO, C., J. M. SÁNCHEZ \& E. COSTILLO. 2003. Patterns of structural complexity and human disturbance of riparian vegetation in agricultural landscapes of a Mediterranean area. Agriculture, Ecosystems and Environment, 95: 495-507.

DE LANGE, D. \& J. C. VAN ZON. 1983. A system for evaluation of aquatic biotopes based on the composition of the macrophytic vegetation. Biological Conservation, 25: 273-284.

DÉCAMPS, H., M. FORTUNÉ, F. GAZELLE \& G. PATOU. 1988. Historical influence of man on the riparian dynamics of a fluvial landscape. Landscape Ecology, 1: 163-173.

DODKINS, I., B. RIPPLEY \& P. HALE. 2005. An application of canonical correspondence analysis for developing ecological quality assessment metrics for river macrophytes. Freshwat. Biol., 50: 891-904.

ESPÍRITO-SANTO, D., P. ARSÉNIO, P. BINGRE, M. SILVEIRA \& I. MOREIRA. 2000. Conservation and restoration of riparian vegetation in South Portugal. Aspects of Applied Biology, 58: 241-248.

EUROPEAN COUNCIL. 2000. Directive 2000/60/EC of the European Parliament and of the Council of 23 October 2000 establishing a framework for Community action in the field of water policy. Official Journal, L327: 1-73.

FERNÁNDEZ-ALAÉZ, C., FERNÁNDEZ-ALAÉZ, M. \& F. GARCÍA-CRIADO. 2005. Spatial distribution patterns of the riparian vegetation in a basin in the NW Spain. Plant Ecology, 170: 31-42.

FERREIRA, M. T. \& F. SMEDING. 1990. Distribution patterns of aquatic and riparian vegetation in the Erra river, central Portugal. Scientia Gerundensis, 16(1): 99-106.

FERREIRA, M. T. \& I. MOREIRA. 1990. Weed evolution and ecology in drainage canals of central Portugal. Proceedings of the 8th International Symposium on Aquatic Weeds. European Weed Research Society. Uppsalla: 97-102.

FERREIRA, M. T. \& I. MOREIRA. 1999. River plants from an Iberian basin and environmental fac- 
tors influencing their distribution. Hydrobiologia, 415: 101-107.

FERREIRA, M. T. \& I. S. MOREIRA. 1995. The invasive component of river flora under the influence of Mediterranean agricultural systems. In: Plant Invasions - General Aspects and Special Problems. P. Pysek., K. Prach, M. Rejmanek \& M. Wade (eds.): 117-127. SPB Academic Publishing, Amsterdam, Netherlands.

FERREIRA, M. T. 1994a. Criação de um índice de avaliação do valor conservacionista de locais dulciaquícolas com base em características habitacionais e macrófitos aquáticos. Actas da $4^{a}$ Conferência Nacional do Ambiente. Lisbon, Portugal: 71-80.

FERREIRA, M. T. 1994b. Macrófitos lóticos do Alto-Alentejo: tipologia e interferências dos ecossistemas agrários envolventes. Recursos Hídricos, 15 (3): 47-58.

FERREIRA, M. T. 1994c. Aquatic and marginal vegetation of the river Divor and its relation with land use. Vehr. Internat. Verein. Limnol., 25: 23042315.

FERREIRA, M. T. 1994d. Gradientes estruturais em vegetação lótica e sua relação com o uso da bacia hidrográfica. Recursos Hídricos, 15 (2): 83-90.

FERREIRA, M. T., \& I. S. MOREIRA. 1990. Impacte das actividades agrícolas sobre a evolução de macrófitos aquáticos no Vale do Sorraia. Proc. $2^{\text {nd }}$ National Conference on Environmental Quality: 264-268.

FERREIRA, M. T., A. ALBUQUERQUE, F. C. AGUIAR \& L. CATARINO. 2001. Seasonal and yearly variations of macrophytes in a southern Iberian river. Verh. Internat. Verein. Limnol., 27: 3833-3837.

FERREIRA, M. T., A. ALBUQUERQUE, F. C. AGUIAR \& N. SIDORKEWICZ. 2002. Assessing reference sites and ecological quality of river plant assemblages from an Iberian basin using a multivariate approach. Archiv für Hydrobiologie, 155(1): 121-145.

FERREIRA, M. T., F. AGUIAR \& I. MOREIRA. 2004. Macrófitos fluviais. Padrões espaciais de distribuição e factores ambientais determinantes. In: Gestão ambiental dos sistemas fluviais. Aplicação à bacia hidrográfica do rio Sado. I. Moreira, M. G. Saraiva \& F. Nunes-Correia (eds.): 247-264. ISAPress, Lisbon, Portugal.

FERREIRA, M. T., F. C. AGUIAR \& C. NOGUEIRA. 2005. Changes in riparian woods over space and time: influence of environment and land use. Forest Ecology \& Management, 212:145-159.

FERREIRA, M. T., F. N. GODINHO \& R. M. CORTES. 1998b. Macrophytes in a southern Iberian river. Vehr. Internat. Verein. Limnol., 26: 1835-1841.

FERREIRA, M. T., L. CATARINO \& I. MOREIRA. 1998a. Aquatic weed assemblages in an Iberian drainage channel system and related environmental factors. Weed Research, 38: 291-300.

FERREIRA, M. T., P. RODRÍGUEZ-GONZÁLEZ, F. C. AGUIAR \& A. ALBUQUERQUE. 2005. Assessing biotic integrity in Iberian rivers: development of a multimetric plant index. Ecological Indicators, 5:137-149.

GALLEGO-FERNÁNDEZ, J. B., M. R. GARCÍAMORA \& F. GARCÍA-NOVO. 1999. Small wetlands lost: a biological conservation hazard in Mediterranean landscapes. Environmental Conservation, 26(3): 190-199.

GASITH, A. \& V. H. RESH. 1999. Streams in Mediterranean climate regions: abiotic influences and biotic responses to predictable seasonal events. Annual Review of Ecology and Systematics, 30: 51-81.

GONZÁLEZ, P. M., M. T. FERREIRA \& D. ESPÍRITO-SANTO. 2003. Aplicação de um índice multimétrico para avaliação da qualidade ecológica de habitats e de galerias ribeirinhas. Recursos Hídricos, 24(2): 79-88.

GONZÁLEZ-BERNÁLDEZ, F., C. LEVASSOR \& B. PECO. 1989. Landscape ecology of uncultivated lowlands in central Spain. Landscape Ecology, 3:3-18.

HANCOCK, C. N. \& R. H. FROEND. 1996. Biodiversity and management of riparian vegetation in Western Australia. Forest Ecology \& Management 85: 239-250.

HASLAM, S. M. 1987. River Plants of Western Europe. Cambridge: Cambridge University Press. $396 \mathrm{pp}$.

HAURY, J., M. C. PELTRE, S. MULLER, M. TRÉMOLIËRES, J. BARBE, A. DUTARTRE \& M. GUERLESQUIN. 1996. Des indices macrophytiques pour estimer la qualité des cours d'eau français: premières propositions. Écologie, 27: 233-244.

HENRY, C. P., C. AMOROS \& G. BORNETTE. 1996. Species traits and recolonization processes after flood disturbances in riverine macrophytes. Vegetatio, 122: 13-27.

HOLMES, N. T. H., J. R. NEWMAN, J. R. CHADD, K. J. ROUEN, L. SAINT \& F. H. DAWSON. 1999. Mean Trophic Rank: a User's Manual. 
Research and Development, Technical Report E39. Environment Agency, Bristol. 134 pp.

HOLMES, N. T. H., P. J. BOON \& T. A ROWELL. 1998. A revised classification system for British rivers based on their aquatic plant communities. Aquatic Conservation: Marine and Freshwater Ecosystems, 8: 555-578.

HOOD W. G. \& R. J. NAIMAN. 2000. Vulnerability of riparian zones to invasion by exotic vascular plants. Plant Ecology, 148: 105-114.

KARR, J. R. \& E. W. CHU. 2000. Sustaining living rivers. Hydrobiologia, 422/423: 1-14.

KONDOLF, G. M., J. W. WEBB, M. J. SALE \& T. FELANDO.1987. Basic hydrological studies for assessing impacts of flow diversions on riparian vegetation: examples from streams of the eastern Sierra Nevada, California. Environmental Management, 11: 757-769.

LYON, J. \& C. L. SAGERS. 2002. Correspondence analysis of functional groups in a riparian landscape. Plant Ecology, 164:171-183.

MALANSON, G. P. 1993. Riparian landscapes. Cambridge University Press, Cambridge. 296 pp.

MOREIRA, I., A. MONTEIRO, M. T. FERREIRA, L.CATARINO, J. C. FRANCO \& T. REBELO. 1999b. Estudos sobre biologia e combate do jacinto aquático (Eichhornia crassipes (Mart. SolmsLaub.)) em Portugal. Garcia da Horta, Série Botânica, 14 (2): 191-198.

MOREIRA, I., M. T. FERREIRA \& A. MONTEIRO. 1989. Aquatic weed bioecology and control in Portugal: a review. In: Portuguese-German Cooperation in Applied Agricultural Results. A. Bianchi (ed.): 71-106. Edições Universidade de Trás-os-Montes e Alto Douro, Vila Real, Portugal.

MOREIRA, I., M. T. FERREIRA \&. C. DUARTE. 2004. Flora de ecossistemas aquáticos e ribeirinhos portugueses: delimitação taxonómica, tipológica e espacial. Recursos Hídricos, 25(1): 67-94.

MOREIRA, I., M. T. FERREIRA, A. MONTEIRO, L. F. CATARINO \& T. VASCONCELOS. 1999a. Aquatic weeds and their management in Portugal: insights and the international context. Hydrobiologia, 415: 229-234.

NAIMAN, R. J., DÉCAMPS, H., POLLOCK, M. 1993. The role of riparian corridors in maintaining regional diversity. Ecological Applications, 3:209212.

NAIMAN, R. J., H. DÉCAMPS \& M. E. MCCLAIN (eds.). 2005. Riparia. Ecology, Conservation, and Management of Streamside Communities. San Diego, USA: Elsevier Academic Press. 345 pp.
NICHOLS, S., S. WEBER \& B. SHAW. 2000. A proposed aquatic plant community biotic index for Wisconsin lakes. Environmental Management, 26: 491-502.

NILSSON, C. \& M. SVEDMARK. 2002. Basic principles and ecological consequences of changing water regimes: riparian plant communities. Environmental Management, 3: 468-480.

NILSSON, C., A. EKBLAD, M. GARDFJELL \& B. CARLBERG. 1991. Long-term effects of river regulation on river margin vegetation. Journal of Applied Ecology, 28: 963-987.

NILSSON, C., G. GRELSSON, M. JOHANSSON \& U. SPERENS. 1989. Patterns of plant richness along riverbanks. Ecology, 70: 77-84.

NOBLE, I. R. \& R. O. SLATYER. 1980. The use of vital attributes to predict successional changes in plant communities subject to recurrent disturbances. Vegetatio, 43: 5-21.

ONAINDIA, M., B. G. BIKUNA \& I. BENITO. 1996. Aquatic plants in relation to environmental factors in northern Spain. Journal of Environmental Management, 47(2): 123-137.

PENUELAS, J. \& F. SABATER. 1987. Distribution of aquatic plants in relation to environmental factors in the Ter river, N.E. Spain. Int. Rev. Ges. Hydrobiol., 78: 41-58.

PLANTY-TABACCHI, A. M., E. TABACCHI, R. J. NAIMAN, C. DE FERRARI \& H. DÉCAMPS. 1996. Invasibility of species-rich community in riparian zones. Conservation Biology, 10: 598607.

RIIS, T., K. SAND-JENSEN \& O. VESTERGAARD. 2000. Plant communities in lowland Danish streams: species composition and environmental factors. Aquatic Botany, 66: 255-272.

ROMERO, M. I. \& M. ONAINDIA. 1995. Fullgrown aquatic macrophytes as indicators of river water quality in the northwest Iberian Peninsula. Ann. Bot. Fennici, 32: 91-99.

SALINAS, M. J., G. BLANCA \& T. ROMERO 2000. Evaluating riparian vegetation in semi-arid Mediterranean watercourses in the south-eastern Iberian Peninsula. Environmental Conservation, 27(1): 24-35.

SCHAUMBURG, J., C. SCHRANZ, J. FOERSTER, A. GUTOWSKI, G. HOFMANN, P. MEILINGES, S. SCHNEIDER \& U. SCHEMEDTJE. 2004. Ecological classification of macrophytes and phytobenthos for rivers in Germany according to the Water Framework Directive. Limnologica, 34:283-301. 
SCHNEIDER, S. \& A. MELZER, A., 2003. The trophic index of macrophytes (TIM) - a new tool for indicating the trophic state of the water. International review Hydrobiology, 88: 49-67.

STOHLGREN, T. J., D. BINKLEY, G. W.CHONG, M. A. KALKHAN, L. D. SCHELL, K. A. BULL, Y. OTSUKI, G. NEWMAN, M. BASHKIN \& Y. SON 1999. Exotic plants invade hot spots of native plant diversity. Ecological Monographs, 69: 25-46.

STROMBERG, J. C., 1993. Instream flow models for mixed deciduous riparian vegetation within a semi-arid region. Regulated River: Research \& Management, 8: 225-235.

SZARO, R. C. \& KING, R. M. 1990. Sampling intensity and species richness: effects of delineating southwestern riparian plant communities. Forest Ecology \& Management, 33-34: 335-349.

SZARO, R. C. 1990. Southwestern riparian plant communities: site characteristics, tree species distributions and size-class structures. Forest, Ecology \& Management, 33/34: 315-334.
TABACCHI, E., A. M. PLANTY-TABACCHI, M. J. SALINAS \& H. DÉCAMPS. 1996. Landscape structure and diversity in riparian plant communities: a longitudinal comparative study. Regulated Rivers: Research \& Management, 12: 367-390.

THIEBAUT, G., F. GUEROLD \& S. MULLER. 2002. Are trophic and diversity indices based on macrophyte communities pertinent tools for monitor water quality? Water Research, 26: 36023610.

WARD, J. V., F. MALARD \& K. TOCKNER. 2002. Landscape ecology: a framework for integrating pattern and process in river corridors. Landscape Ecology, 17: 35-45.

WIEGLEB, G., W. HERR \& D. TODESKINO. 1989. Ten years of vegetation dynamics on rivulets in Lower Saxony (FRG). Vegetatio, 82: 163-178.

WILLBY, N. J., V. J. ABERNETHY \& B. O. DEMARS. 2000. Attribute-based classification of European hydrophytes and its relationship to habitat utilization. Freshwat. Biol., 43: 43-74. 